\title{
DOE Plant-Wide Energy Assessment Results Related to the U.S. Automotive Industry
}

\author{
Robert Leach, Karen McElhaney, Anthony Wright \\ Oak Ridge National Laboratory, One Bethel Valley Road, Oak Ridge, TN 37831-6075
}

Copyright @ 2006 SAE International

\begin{abstract}
Forty-nine plant-wide energy efficiency assessments have been undertaken under sponsorship of the U.S. Department of Energy's Industrial Technologies Program. Plant-wide assessments are comprehensive, systematic investigations of plant energy efficiency, including plant utility systems and process operations. Assessments in industrial facilities have highlighted opportunities for implementing best practices in industrial energy management, including the adoption of new, energy-efficient technologies and process and equipment improvements. Total annual savings opportunities of \$201 million have been identified from the 40 completed assessments. Many of the participating industrial plants have implemented efficiency-improvement projects and already have realized total cost savings of more than \$81 million annually. This paper provides an overview of the assessment efforts undertaken and presents a summary of the major energy and cost savings identified to date. The paper also discusses specific results from assessments conducted at four plants in the automotive manufacturing operations and supporting industries. These particular assessments were conducted at facilities that produce engine castings, plastic films used for glass laminates, forged components, and at a body spray painting plant.
\end{abstract}

\section{DOE AND INDUSTRY PARTNERSHIP FOR ENERGY EFFICIENCY}

The Department of Energy's (DOE) Office of Energy Efficiency \& Renewable Energy's (EERE) Industrial Technologies Program (ITP) has been working with industries that consume significant amounts of energy to improve their energy efficiency. Examples of these energy-intensive industries include the chemical, aluminum, glass, steel, mining, petroleum, and forest products industries. As a part of this effort, ITP has sponsored cost-shared, plant-wide energy assessments of industrial facilities through its BestPractices Program.

DOE promotes plant-wide assessments (PWA) to increase industrial energy efficiency, productivity, global competitiveness, and to reduce emissions. The intent is to build an experience portfolio that can be used throughout industry as a mechanism for dissemination of project results and replication via energy management programs. DOE publishes results of the assessment findings and also conducts follow-up activities to assess overall program effectiveness. Public dissemination of specific implementation and replication experience, however, is at the discretion of the individual companies.

Interested companies have been invited to submit proposals in response to competitive solicitations, usually offered once a year. To date, DOE has issued eight competitive PWA solicitations. Proposals are sought in which industry-defined teams consider adopting best available and emerging technologies using state-of-the-art tools, information, process engineering techniques, and best practices in energy management. The maximum award from DOE is $\$ 100,000$ and requires matching funds or more from industry. Industrial end users are required to submit the proposals, but companies are encouraged to develop and work closely with assessment teams that could include their resource and equipment suppliers, engineering/consulting firms, academia, and other third party entities. Proposals are evaluated based on the breadth and scope of the assessment methodology proposed, potential energy savings, applicability of results to other plants both within and outside the applicant's industrial sector, and qualifications of personnel designated to perform the assessment.

The results and experiences from completed PWAs are published in case studies that are available to the public from DOE. Confidentiality is protected and no proprietary company information, including the final assessment report, is released. By publicizing assessment findings through the case studies and other efforts, DOE encourages other U.S. manufacturers to adopt and implement similar approaches to increasing energy and process efficiency and reducing environmental emissions.

PWAs have been conducted in a variety of industrial sectors. Assessments that have involved auto-related companies (i.e., those that supply products directly to the automotive industry) include Ford, Amcast Industrial 
Corporation, Metaldyne Inc., Jernberg Industries, Inc., and Corning, Inc. Other companies that produce intermediate products for automotive industry suppliers include the Bayer Corporation, Alcoa, Pechiney, Solutia Inc., North Star Steel, Akzo Nobel, and Rohm and Haas.

\section{PLANT-WIDE ASSESSMENT APPROACH AND RESULTS}

A PWA is the application of a systems approach across an entire plant operation. Assessment teams address a variety of generic and industry-specific technology areas and a range of plant/process optimization methods. In addition, energy management best practices in areas such as plant steam, process heating, pumping, and compressed air systems are examined. An assessment typically results in a set of specific projects for improving energy efficiency and productivity and for decreasing waste and emissions. Because of the tremendous differences among industrial facilities' design and operation, there is no generic PWA methodology. The PWA approach involves a systematic, plant-wide assessment that is tailored to the facility by the assessment team; plants are encouraged to identify and employ strategies that can be reapplied elsewhere with similar facilities and/or processes.

Potential energy, cost, and environmental impact savings are estimated for implementation of individual projects. In many cases, projected cost savings result not only from electricity and/or fuel savings, but also from other benefits such as increased productivity, reduced maintenance, reduced production of scrap material, and process improvements. Other benefits resulting from implementation of the assessment recommendations have included reduced waste and environmental emissions and decreased use of natural resources such as fresh water.

Projects identified during the assessments have ranged from simple, low-cost lighting or insulation upgrades to long-term, capital-intensive improvements such as the installation of a high-capacity cupola at Ford's Cleveland, Ohio engine casting plant. Typical projects applicable to most industrial installations include compressed air system upgrade and maintenance, pumping/blower system upgrade, installation of variable speed drives, electric motor management and efficiency improvement, and thermal efficiency improvement. Many projects can also be replicated at multiple facilities within an industrial sector. For example, in the chemicals and petroleum industries, projects commonly involve waste heat recovery, steam use reduction, and cogeneration.

PWAs identify highly customized projects, too. For example, a plan to recover methane gas from a municipal landfill for use in steam boilers or for cogeneration was identified at W. R. Grace's chemical plant near Baltimore, Maryland.

PWAs typically result in a list of several recommendations for each plant. The details of the findings are outlined in a final report developed by the assessment team and submitted to the company and to Oak Ridge National Laboratory (ORNL). ORNL manages the PWA program for DOE.

Although conducting the assessments and performing analyses are the responsibility of the assessment teams, ORNL interfaces with the teams and reviews their reports. Details of the assessment findings are documented in case studies that discuss the assessment approaches that were employed and the specific efficiency improvement opportunities that were identified. Results from completed PWAs have also been disseminated through internal corporate technical reviews, publications, and newsletters, through DOE's Energy Matters newsletter, and by presentation at industry conferences and technical organizations such as the American Institute of Chemical Engineers (AIChE) and the North American Die Casting Association (NADCA).

Assessments have been initiated at 49 facilities through fiscal year 2005. Of these, 40 plants have completed final reports. The combined annual cost savings identified at these facilities is approximately \$201 million. Although total cost savings related to energy use reduction range from less than $10 \%$ up to $100 \%$, depending on the specific assessment, about $60 \%$ of the total identified savings is estimated to be energy-related. Potential annual electric and thermal energy savings are estimated at 539,933,000 kWh and 18,698,000 million $\mathrm{Btu}$ (MMBtu), respectively. Potential annual $\mathrm{CO}_{2}$ savings are estimated to be almost 3.2 billion $\mathrm{lb}$. Average investment payback periods are expected to be less than two years and in many cases is less than a year. Table 1 provides a summary of overall PWA results to date.

Table 1. Summary of DOE Plant-Wide Energy Efficiency Assessment Results

\begin{tabular}{|l|r|}
\hline Number of PWAs initiated & \\
\hline Number of PWAs completed & 49 \\
\hline $\begin{array}{l}\text { Total potential annual cost } \\
\text { savings identified from } \\
\text { completed assessments }\end{array}$ & $\$ 201,000,000$ \\
\hline $\begin{array}{l}\text { Total potential annual } \\
\text { electricity savings identified } \\
\text { from completed assessments }\end{array}$ & $539,933,000 \mathrm{kWh}$ \\
\hline $\begin{array}{l}\text { Total potential annual fuel } \\
\text { savings identified from } \\
\text { completed assessments }\end{array}$ & $18,698,000 \mathrm{MMBtu}$ \\
\hline $\begin{array}{l}\text { Total potential annual CO }{ }_{2} \\
\text { savings identified from } \\
\text { completed assessments }\end{array}$ & $3,151,000,000$ \\
\hline $\begin{array}{l}\text { Number of plants reporting } \\
\text { implementation results }\end{array}$ & \\
\hline $\begin{array}{l}\text { Total annual savings realized } \\
\text { from project implementation }\end{array}$ & $\$ 81,000,000$ \\
\hline \multicolumn{2}{|c|}{ fom } \\
\hline
\end{tabular}




\begin{tabular}{|l|l|}
\hline at PWA plants & \\
\hline $\begin{array}{l}\text { Total annual savings realized } \\
\text { from project replication }\end{array}$ & $\$ 73,000,000$ \\
\hline
\end{tabular}

\section{ENERGY EFFICIENCY ASSESSMENTS CONDUCTED IN THE AUTOMOTIVE AND SUPPORTING INDUSTRIES}

\section{FORD CLEVELAND CASTING PLANT}

The Ford Cleveland Casting Plant in Cleveland, Ohio produces cast iron engine blocks and engine components for Ford plants throughout North America. The plant is part of a complex that includes two engine plants, an aluminum casting plant, and a central power plant. The central power plant distributes steam, compressed air, and electricity to the four production plants - the core shop, mold shop, melt shop and finish shop. The plant purchases electricity, natural gas, water, coke and steam. A two-part assessment methodology was used: (1) characterization, to identify the components of the production processes that had the greatest savings potential, and (2) "inside-out" analysis to identify specific savings opportunities that maximized savings while minimizing capital costs.

Working with plant personnel, the assessment team identified 16 energy- and cost-saving projects for shortterm consideration. These projects addressed a variety of issues, including combustion, compressed air, water, steam, motor drives, and lighting system efficiency.

For example, one project to use supersonic oxygen lancing to improve the temperature profile in the cupola would have certain advantages:

- The melt rate would increase,

- The spout temperature would increase,

- Coke requirements would be reduced, and

- Exhaust gas emissions should decrease.

The assessment team estimated that this project would save more than 2.7 million $\mathrm{kWh}$ of electricity and 49,000 MMBtu in fuel each year. Annual cost savings would be more than $\$ 465,000$.

The team reasoned that supersonic oxygen injection would provide better performance than the plant's traditional practice of using simple oxygen injection to enrich the blast air because it provides oxygen to where it is needed - toward the center of the cupola and away from the water-cooled walls. This would increase the cupola center temperature. Resulting benefits would be derived from two factors: (1) an increase in the spout temperature would cause a decrease in the heat required by the induction furnaces and a slight increase in the melt rate; (2) heat lost to the cupola shell cooling water would be reduced. Implementation costs were estimated to be $\$ 10,000$.
Together, the 16 projects comprised $\$ 3.3$ million per year in cost savings, with an estimated implementation cost of $\$ 2.3$ million. The overall simple payback was less than one year. Implementing the short-term projects could save about 18 million kWh and nearly 139,000 MMBtu per year, plus reduce carbon dioxide $\left(\mathrm{CO}_{2}\right)$ emissions by about 63 million pounds per year. In addition, the assessment team identified two projects for long-term consideration, including installation of a highcapacity cupola. Implementing these projects could save another \$9.5 million per year and produce energy savings of more than 8 million kWh in electricity and more than 600,000 MMBtu in fuel.

\section{METALDYNE}

Metaldyne, Incorporated, is the largest independent forging company in North America. Metaldyne's products include wheel hubs, spindles, rolled rings, and transmission and differential gears. Metaldyne recently completed a PWA at its forging facility in Royal Oak, Michigan. The assessment addressed opportunities to increase energy efficiency, reduce waste and pollutants, and increase productivity by evaluating demand-side energy management, best practices, the use of emerging technologies, and potential supply-side improvements. Although the assessment focused on the plant's large energy-using systems and equipment, the assessment team also evaluated product inventory and the potential for reducing or even eliminating defects, which could also increase the plant's energy efficiency. Lean manufacturing techniques, best practices, and the use of emerging technologies that could improve plant efficiency were also considered.

The assessment team proposed more than 20 projects to save energy and money at the Royal Oak Plant. For example, the team recommended that the plant consider options for in-house controlled cooling of forged parts that were being outsourced for heat treating. The options were (1) to use a batch-type cooling system, in which parts are placed in bins and cooled under controlled temperature and time conditions immediately after being forged, and (2) to use a batch-type system to control the cooling of parts produced from the ring rolling machines, and two continuous (spiral) systems to handle single parts produced directly from the Hatebur presses. If cooling bins were used, the batch-type systems should feature high-convection recirculating air flow to ensure uniform cooling of all the parts. Implementation of this project could save more than $\$ 6.6$ million per year.

Another project proposed by the assessment team was to increase life of the forging tools (punches and dies) by maintaining cooler tool surfaces. This could be accomplished by reducing the cooling water temperature and by applying a lubricating coating to the tool surface. Longer tool life would increase the productivity of the forging presses, reduce press downtime, increase throughput, and reduce overall production costs. The team estimated that this project would save more than 4.4 million $\mathrm{kWh}$ and $\$ 3.5$ million annually. 
If all the projects identified during the Royal Oak plantwide study were implemented, the assessment team estimated that total annual energy savings for electricity would be more than 11 million $\mathrm{kWh}$. Total annual cost savings were estimated to be $\$ 12.6$ million. Payback for all projects combined would be about six months.

SOLUTIA, INC.

During the PWA conducted at Solutia's chemical production facility in Springfield, Massachusetts, the assessment team focused on finding ways to reduce the site-wide use of steam, electricity, compressed air, and water. Solutia, Inc. produces performance films for laminated safety glass and after-market film applications. Solutia's team was composed of process experts, utility engineers, research and development scientists, cost estimators, accountants, process and project engineers, and external consultants.

The assessment employed the Steam, Electricity, Cooling Utility Reduction Exercise (SECURE) methodology to address both the process and utility sides of the site's operations. This methodology considers the site as an integrated entity rather than a disparate collection of individual processes. For production processes, the assessment team collected data on steam, electricity, water, and wastewater usage and costs. They also compiled data on energy use for individual process equipment. The team then analyzed this information to identify the primary energy users and each one's potential for energy savings. If all 80 projects identified during the study were implemented, the total estimated annual energy savings would be about 9.5 million kWh and more than 338,000 MMBtu. At an investment of $\$ 6.3$ million, total annual cost savings were estimated to be nearly $\$ 3.3$ million. Average payback for all projects would be approximately 2 years.

One project proposed during the study was to use waste heat from the air compressor to preheat boiler feedwater. The site has a centralized air compressor system, and the air compressors generate a significant amount of waste heat. The compressors have a closedloop cooling system so that coolant-to-air heat transfer is accomplished by using several undersized heat exchangers. These heat exchangers operate at elevated temperatures during summer months, so they must be cooled by a water spray system. The assessment team recommended capturing waste heat from the air compressors and using it to preheat the boiler feedwater. Inadequate air coolers could also be replaced with two new plate-type heat exchangers. This project would save $\$ 208,000,35,000 \mathrm{MMBtu}$, and 159,000 kWh annually if implemented.

Other projects to install variable frequency drives on chilled water pumps, cooling tower water pumps, cooling tower fans, chiller motors, hot water pump east, boiler feedwater pump, the biofilter supply fan, dryer exhaust fan, biofilter scrubber pump, boiler fans, and the B crude pump would collectively save an estimated $\$ 555,000$ and more than 6.5 million $\mathrm{kWh}$ per year.

\section{FORD MICHIGAN TRUCK PLANT}

The Ford Michigan Truck Plant in Wayne, Michigan, produces Expedition and Navigator sport utility vehicles. The facility is divided into a body plant, paint plant, and final assembly plant. The PWA focused on the paint plant, where most of the energy consumed is used to provide conditioned air to the painting booths and dry-off ovens and for cleaning the air before discharging it to the environment. The painting process has five principle operations: phosphate cleaning, E-coat application, sealer application, primer application, and color application. In the color operation, vehicles pass through either the tutone or enamel painting booths and ovens. Vehicle bodies are conveyed through each operation on an assembly line and pass through dry-off ovens after each operation except phosphate cleaning.

With the help of plant facilities and maintenance personnel, the assessment team collected data on processes, equipment, plant operation, and energy use. Statistical models were developed to predict energy use for budgeting, measuring savings, or diagnostic purposes. The statistical models were also used to break down plant energy use into facility, spaceconditioning, and production-dependent components and to estimate potential savings from reducing nonproduction and 
non-weather-dependent energy use. Based on their analysis, the assessment team identified 27 energy savings opportunities. Near term savings opportunities were estimated to have a total potential savings of about \$3.8 million per year and a combined simple payback of about 19 months. The team also identified about $\$ 2.3$ million per year in long-term savings opportunities.

One project proposed by the assessment team involved using clean air from the carbon beds for the air supply houses. The air supply houses for the paint booths use ambient air that is heated to $75^{\circ} \mathrm{F}$ and conditioned to maintain the appropriate humidity level. Ambient air is heated by mixing it with hot air from gas-fired burners; humidity is controlled by spraying water into the hot air. The heat requirement for controlling the temperature and humidity for the air depends on the ambient conditions outside the plant. The water has to be evaporated to mix with the air. The heat of evaporation is taken from the heated air. The burner heat input is sized to supply heat for extremely cold weather conditions; however, the heat requirement is reduced during the summer months. Similarly, the water flow requirement varies with outdoor ambient conditions.

At the same location, the plant uses a carbon bed to adsorb volatiles from paint booth air. This air is clean and is currently discharged into the atmosphere. Normally, the air temperature discharged from the carbon beds is approximately $90^{\circ} \mathrm{F}$. The air from the carbon beds contains more heat than necessary to heat the ambient air and can be used to replace colder ambient air for the air supply houses for the paint booths. It is likely that some of the excess heat would be lost from the ducts that connect the carbon beds to the air supply houses; however, with proper insulation these heat losses can be minimized.

The assessment team recommended that the plant use air from the carbon beds in the air supply houses when the outdoor temperature is below $75^{\circ} \mathrm{F}$. The air requirement for the air supply houses is greater than the air coming from the carbon beds, hence only a part of the air supply house air demand would be met by the carbon bed air. However, the carbon bed air is warmer, so the excess heat could be used to supply heat to the colder incoming air for the air supply houses. Energy savings in the heating system would be realized by reducing the amount of ambient air that needs to be heated to $75^{\circ} \mathrm{F}$ in the air supply houses.

The team estimated that if this project were implemented, the company would save more than 34,000 MMBtu/year (although their electricity use would increase by slightly more than $500,000 \mathrm{kWh} / \mathrm{yr}$ ). Cost savings were estimated at $\$ 164,000 / y r ;$ payback for this project would be about 14 months.

\section{WHAT CAN YOU DO?}

There are a number of DOE-sponsored resources available for industrial end users that can help improve efficiency and reduce costs at your plant.

\section{PARTICIPATE IN A PLANT-WIDE ASSESSMENT}

Plant-wide energy assessments investigate overall energy use in industrial facilities-which can account for $10 \%$ or more of a plant's total operating cost-and identify cost-effective measures for best practices in energy management, including the adoption of new energy-efficient technologies and process and equipment improvements.

Plants that conduct assessments and implement identified savings can reasonably expect a $10 \%$ to $15 \%$ reduction in energy costs and also improvements in productivity and waste reduction. Average payback period is usually less than two years. In addition, the findings from a single assessment may be replicated in other corporate facilities with similar process systems, utility systems, or equipment, and with comparable energy use.

\section{TAKE ADVANTAGE OF DOE TOOLS AND RESOURCES}

BestPractices offers a variety of system-wide and component-specific tools and resources to help improve industrial plant energy efficiency. DOE encourages industrial end users to utilize these tools and resources to improve their energy management and to facilitate decision-making.

\section{UTILIZE SOFTWARE TOOLS}

As a part of the BestPractices efforts, a suite of tools has been developed to assist industrial plant personnel to identify energy efficiency improvements to their plant process and utility systems. The software tools that are presently available are listed and briefly described in Table 2.

All of the software tools focus on energy efficiency assessments; i.e., quantifying the potential savings that are available for a specific improvement opportunity. For example, in steam systems this might be savings that result from increasing condensate return. For process heating, this could be savings that result from reducing excess oxygen in furnaces.

DOE has partnered with key trade associations and focused technical groups to develop the software tools. For example, DOE has worked with the Hydraulics Institute to develop the pump tool, with the International Heating Equipment Association to develop the process heating tool, and with the Air Movement and Controls Association to develop the fan tool. 
To assist industrial plant personnel and utility system service providers in applying the software tools, DOE has developed two types of training:

\section{End user training}

Typically one day in length, end user training focuses on reviewing key savings opportunities available for individual plant utility and process systems. It also introduces the specific software tools. Presently, end user training is available for motors, compressed air systems, pumping systems, steam systems, process heating systems, and fan systems.

\section{Specialist qualification training}

Typically 2 to 2-1/2 days in length, specialist qualification training specifically focuses on how to effectively use individual BestPractices software tools. Trainees who pass an exam are granted the designation of Qualified Specialist for a specific software tool. Specialist qualification training is currently available for the compressed air, pump, steam, process heating, and fan software tools.

\section{FIND OUT ABOUT INDUSTRIAL ASSESSMENT CENTERS}

ITP also sponsors Industrial Assessment Centers (IAC) that provide eligible small- and medium-sized manufacturers with limited-scope energy assessments. Additionally, the IACs serve as a training ground for the next-generation of energy savvy engineers. Teams composed mainly of engineering faculty and students from the centers, located at 26 universities around the country, conduct energy audits or industrial assessments and provide recommendations to manufacturers to help them identify opportunities to improve productivity, reduce waste, and save energy. Recommendations from industrial assessments have averaged about $\$ 55,000$ in potential annual savings for each manufacturer.

\section{UTILIZE COLLABORATIVE TARGETED ASSESSMENTS}

Collaborative Targeted Assessments (CTA) are selectively provided in conjunction with DOE training based on replication potential. DOE experts work in partnership with plant teams to apply a systems approach in assessing specific systems (e.g., pumping) and to identify opportunities for savings. CTAs are used as a way to develop in-plant expertise in applying DOE tools and systems optimization methods and as a stepping stone to the implementation of plant and company-wide adoption of best practices for energy management of targeted energy systems. 
Table 2. Software Tools that Help Identify Efficiency Improvement Opportunities

\begin{tabular}{|c|c|}
\hline Tool & Description \\
\hline MotorMaster+ & $\begin{array}{l}\text { Identifies inefficient or oversized motors; computes energy and demand savings } \\
\text { associated with selection of replacement energy-efficient models; includes motor } \\
\text { inventory management, maintenance logging, and a motor price and performance } \\
\text { database. }\end{array}$ \\
\hline $\begin{array}{l}\text { Pumping System } \\
\text { Assessment Tool (PSAT) }\end{array}$ & $\begin{array}{l}\text { Assesses efficiency of pumping system operations; uses achievable pump } \\
\text { performance data from Hydraulic Institute standards and motor performance data from } \\
\text { MotorMaster+ database to calculate potential energy and associated cost savings. }\end{array}$ \\
\hline AirMaster+ & $\begin{array}{l}\text { Assesses compressed air systems; models existing/future system upgrades; evaluates } \\
\text { savings/effectiveness of energy efficiency measures. }\end{array}$ \\
\hline $\begin{array}{l}\text { Steam System Scoping } \\
\text { Tool (SSST) }\end{array}$ & $\begin{array}{l}\text { Evaluates a facility's steam system operations and management practices against best } \\
\text { practices. }\end{array}$ \\
\hline $\begin{array}{l}\text { Steam System } \\
\text { Assessment Tool (SSAT) }\end{array}$ & $\begin{array}{l}\text { Estimates impacts of key steam system improvements; provides energy, cost, and } \\
\text { emission savings results for up to sixteen different steam improvement opportunities. }\end{array}$ \\
\hline 3E Plus & $\begin{array}{l}\text { Calculates the most economical thickness of industrial insulation for a given set of } \\
\text { operating conditions; performs calculations using the built-in thermal performance } \\
\text { relationships of generic insulation materials or user-supplied conductivity data for other } \\
\text { materials. }\end{array}$ \\
\hline $\begin{array}{l}\text { Process Heating } \\
\text { Assessment and Survey } \\
\text { Tool (PHAST) }\end{array}$ & $\begin{array}{l}\text { Surveys process heating equipment; identifies major energy-intensive equipment; } \\
\text { performs energy (heat) balances on selected equipment (furnaces) to identify/reduce } \\
\text { non-productive energy use; compares performance of furnaces under various } \\
\text { operating conditions and tests "what if" scenarios. }\end{array}$ \\
\hline $\begin{array}{l}\text { Fan System Assessment } \\
\text { Tool (FSAT) }\end{array}$ & $\begin{array}{l}\text { Calculates amount of energy used by fan systems; determines fan system efficiencies; } \\
\text { quantifies savings potentials of upgraded fan systems. }\end{array}$ \\
\hline $\begin{array}{l}\text { NOx and Energy } \\
\text { Assessment Tool } \\
\text { (NxEAT) }\end{array}$ & $\begin{array}{l}\text { Assesses/analyzes NOx emissions and applications of energy efficiency } \\
\text { improvements at petroleum refining and chemical plants; inventories emission from } \\
\text { NOx generating equipment; compares various technology applications and efficiency } \\
\text { measures that affect overall costs and reduction of NOx; performs "what if" analyses to } \\
\text { optimize and select the most cost-effective methods of reducing NOx. }\end{array}$ \\
\hline ASDMaster & $\begin{array}{l}\text { Determines economic feasibility of adjustable speed drive (ASD) applications; predicts } \\
\text { electrical energy savings from using ASDs. Available by contacting Electric Power } \\
\text { Research Institute (EPRI). }\end{array}$ \\
\hline $\begin{array}{l}\text { Plant Energy Profiler for } \\
\text { the Chemical Industry } \\
\text { (ChemPEP) }\end{array}$ & $\begin{array}{l}\text { The ChemPEP Tool provides information needed to identify savings and efficiency } \\
\text { opportunities. The ChemPEP Tool enables energy managers to view overall plant } \\
\text { energy use, identify major energy-using equipment and operations, summarize energy } \\
\text { cost distributions, and pinpoint areas for more detailed analysis. This tool provides } \\
\text { plant energy information in an easy-to-understand graphical format. }\end{array}$ \\
\hline
\end{tabular}

\section{GET ADDITIONAL INFORMATION}

Companies interested in participating in performing energy-efficiency assessments can access additional information at the OIT website (www.eere.energy.gov/ industry/bestpractices). Case studies summarizing experience from completed PWAs are also available at this site under BestPractices Tools and Publications.

All of the software tools (except ASDMaster) are available free of charge; the tools can be downloaded from the DOE website. Additional information on IACs and CTAs can also be found at the site. 


\section{CONCLUSIONS}

Historically, U.S. industries have failed to place a high priority on energy efficiency improvements because of its relatively cheap cost. A significant part of the incentive for development of DOE's PWA program was therefore to increase industries' awareness of measures to save energy and reduce operating costs. To date, the program has provided the impetus for 40 industrial facilities to identify $\$ 201$ million in potential annual cost savings, including nearly 540 million kWh in electricity savings and almost 19 million MMBtu in fuel. \$81 million in annual savings has already been realized from project implementation at the plants completing the assessments, and corporate replication has accounted for an additional $\$ 73$ million/year. Additionally, implementation of projects identified during the assessments has resulted in many cases in increased productivity, reduced maintenance and downtime, reduced scrap production, process improvements, and/or reduced waste and environmental emissions.

\section{REFERENCES}

Ford Cleveland: Inside-Out Analysis Identifies Energy and Cost Savings Opportunities at Metal Casting Plant

DOE/GO-102003-1678, September 2003

Metaldyne: Plant-Wide Assessment at Royal Oak Finds Opportunities to Improve Manufacturing Efficiency, Reduce Energy Use, and Achieve Significant Cost Savings

DOE/GO-102005-2119, May 2005

Solutia: Massachusetts Chemical Manufacturer Uses SECURE Methodology to Identify Potential Reductions in Utility and Process Energy Consumption

DOE/GO-102005-2120, July 2005

Final report: Plant Wide Assessment for Ford Michigan Truck Plant Paint Shop

Kelly Kissock, Arvind Thekdi, Len Bishop, June 2005 